\title{
Research Paper \\ The Prevalence of Bacteruria and Its Relationship With ABO Blood Group in Pregnant Women
}

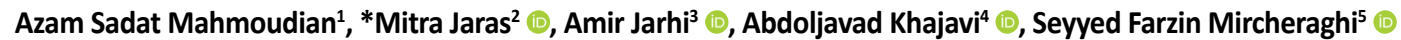

1. Department of Obstetrics and Gynecology, School of Medicine, Gonabad University of Medical Sciences, Gonabad, Iran.

2. Department of Community Health Nursing, School of Nursing, Arak University of Medical Sciences, Arak, Iran.

3. Department of General Education, School of Medicine, Gonabad University of Medical Sciences, Gonabad, Iran.

4. Department of Social Medicine and Health, Social Development and Health Promotion Research Center, School of Medicine, Gonabad University of Medical Sciences, Gonabad, Iran.

5. Department of Internal Medicine, School of Medicine, Gonabad University of Medical Sciences, Gonabad, Iran.

\begin{tabular}{l|l}
$\begin{array}{c}\text { Use yourdevice to san } \\
\text { and read the article online }\end{array}$ & $\begin{array}{l}\text { Cftation Mahmoudian AZ, Jaras M, Jarhi A, Khajavi A, Mircheraghi SF. [The Prevalence of Bacteruria and Its Relationship With } \\
\text { ABO Blood Group in Pregnant Women (Persian)]. Quarterly of "The Horizon of Medical Sciences". 2021; 27(3):302-317. https:// } \\
\text { doi.org/10.32598/hms.27.3.3213.1 }\end{array}$ \\
dolihttps://doi.org/10.32598/hms.27.3.3213.1
\end{tabular}

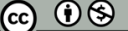

Received: 28 Jul 2019

Accepted: 04 Apr 2021

Available Online: 01 Jul 2021

Key words:

Bacteriuria, ABO

blood groups, Preg-

nant women

\section{ABSTRACT}

Aims Blood Group Antigens ( $A B O$ ) are present on the surface of all cells, including urinary tract cells. Besides, they are a predisposing factor for infection in various parts of the body. The present study aimed to determine the prevalence of bacteriuria and its relationship with different blood groups.

Methods \& Materials This descriptive-analytical (cross-sectional) study was performed in 2019 on 400 pregnant women who were selected by convenience sampling method. For each pregnant woman referring to Allameh Behlool Hospital in Gonabad City, Iran, a form including patients' demographic characteristics, medical history, and blood type was completed. Data analysis was performed in SPSS using descriptive statistics and the Chi-squared test. The significance level of the tests was considered $\mathrm{P}<0.05$. Findings Of the explored 400 pregnant women with a Mean \pm SD age of $27.31 \pm 5.9$ years, 58 were bacterially positive. There was a significant relationship between bacteriuria and $A B O$ blood groups $(P=0.001)$. The examined pregnant women with blood groups $O(48.3)$ and $B(29.3)$ were at higher risk of bacteriuria. There was a significant relationship between bacteriuria and gestational age $(\mathrm{P}=0.016)$; accordingly, $56.9 \%$ of the study subjects with bacteriuria were in the third trimester. There was no significant relationship between bacteriuria and educational level $(P=0.944)$, and place of residence $(P=0.494)$.

Conclusion The prevalence of bacteriuria among referred pregnant women was measured to be $14.5 \%$. Moreover, pregnant women in the third trimester of pregnancy with blood types $\mathrm{O}$ and $\mathrm{B}$ were at higher risks for bacteriuria. Therefore, considerations, such as advising this group about the susceptibility to bacteriuria and urinary tract infections, personal hygiene, and faster referral for diagnostic and therapeutic measures if presenting symptoms, as well as informing doctors and obstetricians about this condition and help to make faster decisions are recommended in this respect.

\section{* Corresponding Author:}

Mitra Jaras

Address: Department of Community Health Nursing, School of Nursing, Arak University of Medical Sciences, Arak, Iran.

Tel: +98 (86) 34173507

E-mail: m.jaras@arakmu.ac.ir 


\section{Extended Abstract}

\section{Introduction}

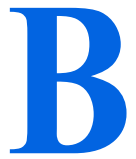

acteriuria is any colonization of bacteria in the urinary tract. Bacteriuria may be symptomatic or asymptomatic. Bacteriuria is a symptom of bacterial colonization in the urine that causes urinary or systemic symptoms. Bacteriuria can occur in the upper urinary tract (pyelonephritis) or involve the lower urinary tract (cystitis and urethritis). Asymptomatic bacteriuria is significant bacterial colonization of the lower urinary tract without symptoms [1]. Urinary tract infections are the most frequent bacterial infections that affect human health [2]; they cause approximately 150 million deaths per year due to this infection and its associated complications, worldwide [3]. If the frequency of bacteria in one milliliter of urine equals $\geq 100000$, the diagnosis is established [4]. Pregnancy increases the odds of getting a urinary tract infection [5].

The most common bacterial infection is during pregnancy, which may be symptomatic or asymptomatic [6]. In pregnant women, due to physiological and anatomical changes in the urinary tract, alternations in the immune system during this period increase the prevalence of bacteriuria, which poses serious risks to the mother and fetus. Additionally, the uterus is located directly above the bladder; thus, it grows and gains weight during pregnancy, which can block the flow of urine from the bladder, leading to infection. The higher levels of progesterone reduce the stretch of the uterine muscles, forcing them to expand in the same place, which reduces urinary flow; as a result, the bacteria have more time to multiply. Furthermore, during pregnancy, urinary acidity decreases, and concurrently, glucosuria increases the potential for bacterial growth [7] and increasing age, diabetes, sickle cell anemia, the history of urinary tract infection, urinary tract disorders, immune system deficiency, the risk of urinary tract infection in pregnant women increases $[3,8]$. The overall prevalence of bacteriuria in Iranian pregnant women was reported to be $2 \%-41 \%[9,10]$. The rate of urinary tract infections in developing countries is estimated to be $\geq 250$ million per year [11].

Studies in different communities suggested that gramnegative bacilli are the most frequent etiological cause of urinary tract infections; among which, Escherichia coli accounts for $>80 \%$ of acute urinary tract infections [2]. Among gram-negative bacteria, in addition to Escherichia coli, Proteus Vulgaris, Klebsiella pneumonia, Staphylococcus epidermidis, Enterobacter, Citrobacter, and Pseudomonas aeruginosa are involved in urinary tract infections $[12,13]$. Unlike other patients, the lack of diagnosis and timely treatment of bacteriuria in pregnancy can be associated with severe complications, such as pyelonephritis, preterm delivery, abortion, preeclampsia, hypertension, amniotitis, low birth weight baby, and anemia $[14,15]$. Bacterial treatment during pregnancy reduces the risk of these complications. Therefore, screening for early detection and treatment of bacteriuria is essential to prevent its complications [16].

Bacteriuria is evident at the time of the first prenatal visit. Besides, after an initial negative urine culture, $<1 \%$ of women develop a urinary tract infection [17]. In individuals with chronic urinary tract infections, bacteria can attach to cells in the urinary tract. Besides, bacterial binding is involved in the colonization of host mucosal surfaces and the inhibition of host defense [18]. Studies revealed that numerous infections are idiopathic. It is essential to understand the potential risk factors for infection. One of these critical factors is the strength of the bacteria to bind to the receptor of carbohydrate antigens on the surface of the cells of the host urinary tract. The glycoprotein at the end of these antigens is the main site of bacterial binding. Blood group antigens $(\mathrm{A}, \mathrm{B}, \mathrm{O})$ are present on the surface of all cells, including urinary tract cells. Moreover, they are considered a predisposing factor for infection in various parts of the body [19].

Blood groups are a system of erythrocyte antigens that can be used by bacteria to attach to cells in the body. Additionally, the attachment of bacteria to host cells is a crucial step in the development and spread of the disease. Susceptibility to some diseases, including infections, cardiovascular disease, and neoplasms, is higher in individuals with certain blood groups. Furthermore, multiple studies highlighted the importance of blood group antigens to disease [20]. Strains that cause urinary tract infections have special virulence factors that impact their accumulation and adhesion to the surface of host mucosal cells and the inhibition of its immune system and contribute to the progression and development of the disease. Immunohematological research on blood group antigens and susceptibility to some diseases has become significant. This is because these antigens may create favorable conditions in an individual to contract some diseases [21].

Susceptibility to some diseases, including infections, is higher in individuals with certain blood groups. Accordingly, extensive research signified the importance of blood group antigens to these diseases [19]. The role of ABO blood type was explored in several infectious diseases [22]. Harris et al. reported the association between blood type $\mathrm{O}$ and the increased severity of cholera symptoms [23]. Moreover, a study conducted in Africa provided convincing evidence that blood group $\mathrm{O}$ is as- 
sociated with a reduced risk of severe malaria [24]. A study revealed that children with blood group A present a greater susceptibility for neuroirus infection, while the $\mathrm{AB}$ blood group is less infected than other groups [25]. Numerous risk factors are recognized for urinary tract infections, such as gender, aging, and diabetes; however, there are other risk factors, including cell surface antigens such as blood types. Genetic susceptibility to urinary tract infections remains poorly studied [26]. Some studies suggested that certain phenotypes of blood groups in the population may identify individuals at high risk for urinary tract infections [27, 28]. Other studies concluded that specific phenotypes protect against microbial colonization in the urinary tract $[22$, 29]. Therefore, this study aimed to investigate the prevalence of bacteriuria and its relationship with different blood groups in pregnant women.

\section{Materials and Methods}

This cross-sectional study was performed to investigate the prevalence of bacteriuria and its relationship with blood type in pregnant women in Gonabad City, Iran. The study participants were selected by the census method. The statistical population of this study consisted of 400 pregnant women who were referred to Allameh Behlool Gonabadi Hospital, in 2019. For each pregnant woman referring to this Hospital and gynecology clinic, a form, including patients' details (residence place, educational level, gestational age), medical history, and blood type were completed. Accordingly, they were referred to the laboratory for a complete urine test and urine sample collection. They were prepared in sterile medium and examined and diagnosed for complete urine tests. The sample size with $95 \%$ confidence level, $80 \%$ test power, and 0.05 error was determined to be $400\left(n=\left((Z 1-\alpha / 2+Z 1-\beta)^{2} P(1-P)\right) / d^{2}=400\right)[30]$. All examined women were identified by blood type during pregnancy. Moreover, blood type was determined using the ABO kit. The standard method for determining blood groups was tubular in two direct and indirect methods. For the direct method, a CBC blood sample was used and for the indirect method, a clot blood sample was employed. The U/A test was used for the urine test.

In this study, the urine samples of pregnant women who were referred to Gonabad Hospital and Clinic of Gonabad University of Medical Sciences were collected by the clean middle urine method (Midstream Clean Catc in sterile dishes, i.e., incubated in non-selective blood agar medium; Pronadisa Microbiological Culture Media and Diagnotic Reagent, Spain) for 24 hours at $37^{\circ} \mathrm{C}$. The obtained samples with a colony count of $\geq 10^{5} \mathrm{~mL} / \mathrm{CFU}$ were considered positive.
$\mathrm{ABO}$ and $\mathrm{Rh}$ blood groups were determined using the Lorne Blood Grouping Reagents kit (UK). The blood type tests were performed by the Typing Cell or Typing Forward and Typing Back or Typing Reverse Tube methods. Initially, blood type was determined by the tubular cell typing method. First, erythrocytes were washed with physiological saline, and a $3 \%$ suspension of erythrocytes in physiological saline was prepared. Besides, 3 tubes were identified for anti-A, anti-B, anti-D, and one drop of each reagent, and the cell suspension was added to each tube and mixed. It was then centrifuged at $1500 \mathrm{rpm}$ for 20 seconds. We gently removed the sediment from the end of the tube and the test result was read under a microscope. The blood type was then re-determined by the tubular Back Typing method. Due to the presence of rare and sub-blood groups, this method was performed using the individual serum to confirm the cell type method. Accordingly, 3\% suspension of red blood cells A, B, and $\mathrm{O}$ was poured into 3 tubes, respectively. Next, 2 drops of unknown serum were added to each tube. The contents of the tubes were mixed and centrifuged at $1500 \mathrm{rpm}$ for 20 seconds. Then, the tubes were gently shaken in the light and examined for agglutination. In case of coordination between type Back and type Cell, the result of the blood group was reported.

The inclusion criteria of the study were as follows: Pregnant women aged 15-45 years, no history of surgery on the urinary system, and providing a written informed consent form to participate in the study. The exclusion criterion of the study was the non-cooperation of pregnant women in the research process. After data collection, data entry into SPSS was performed and the collected data were screened and cleared. The obtained data related to qualitative variables were described using tables and reporting numbers and percentages. Moreover, quantitative variables were reported by mean and standard deviation values. Furthermore, data analysis was performed with appropriate parametric and non-parametric statistical tests (e.g., Chi-squared test), and the results were interpreted at a significance level of 0.05 .

\section{Results}

This study examined 400 pregnant women with a Mean \pm SD age of $27.31 \pm 5.9$ years. Of them, 58 subjects were positive for bacteriuria and 342 were negative, with a bacteriuria prevalence of $14.5 \%$.

The frequency distribution of the explored pregnant mothers was as follows: pregnant women had blood groups $\mathrm{O}$ $(46.2 \%), \mathrm{A}(29.8 \%), \mathrm{B}(14.5 \%), \mathrm{AB}(9.5 \%)$, in terms of gestational age, they were in 3 the first month $(28 \%)$, the second quarter (19.8\%), the third quarter $(52.2 \%)$. Respecting the place of residence, $75.8 \%$ of the study participants were 
Table 1. Bacterial frequency distribution

\begin{tabular}{cc}
\hline Bacteriuria & No. (\%) \\
\hline Yes & $58(5.14)$ \\
\hline No & $342(5.85)$ \\
\hline Total & $400(100)$ \\
\hline
\end{tabular}

Quarterly of

The Horizon of Medical Sciences

urban residents and $24.2 \%$ were rural residents. Concerning educational level, $54.8 \%$ of the research units were university students and $45.2 \%$ were non-university students.

Frequent distribution in pregnant women without bacteriuria was as follows: The frequency distribution of blood group: $45.9 \%$ of blood group $\mathrm{O}, 31.6 \%$ of blood group $\mathrm{A}$, $12 \%$ of blood group $\mathrm{B}, 10.5 \%$ of blood group $\mathrm{AB}$. In terms of gestational age, $30.4 \%$ were in the first trimester, $18.1 \%$ in the second trimester, and $51.5 \%$ in the third trimester. Respecting the place of residence, $24.9 \%$ lived in rural areas and $75.1 \%$ in urban areas. Concerning educational level, $45.3 \%$ had no university education and $54.7 \%$ had a university education.

Frequent distribution in pregnant women with bacteriuria was as below: The frequency distribution of blood group: $48.3 \%$ were blood group O, 19\% were blood group A, $29.3 \%$ were blood group B, 3.4\% were blood group AB. In terms of gestational age, $13.8 \%$ were in the first trimester, $29.3 \%$ in the second trimester, and $56.9 \%$ in the third trimester. Respecting the place of residence, $20.7 \%$ lived in rural areas and $79.3 \%$ in urban areas. Concerning education, $44.8 \%$ had no university education and $55.2 \%$ had a university education. In this study, 58(14.5\%) study subjects presented bacteriuria (Table 1).

To compare bacteriuria and blood groups, a Chi-squared test was used; the relevant data indicated a significant re- lationship between bacteriuria and blood group $(\mathrm{P}=0.001)$ (Table 2). There was a relationship between bacteriuria and gestational age in the study subjects $(\mathrm{P}=0.016)$. Moreover, there was no relationship between bacteriuria and the place of residence $(\mathrm{P}=494)$, and the level of education in the study participants $(\mathrm{P}=0.944)$ (Table 3$)$.

\section{Discussion}

This study investigated the prevalence of bacteriuria and the relationship between $\mathrm{ABO}$ blood type and bacteriuria in pregnant women referring to Allameh Behlool Gonabadi Hospital. Annually, 11\% of women presented urinary tract infections and $>50 \%$ of them manifested these infections during their lifetime. Treating this problem is very expensive and can also cause numerous complications. Multiple infections are idiopathic; thus, it is essential to the associated find risk factors with the infection. Therefore, by examining individuals and trying to find the prevalence of urinary tract infections as well as several risk factors for urinary tract infections, new risk factors such as cell surface antigens, like blood type are also proposed [31].

The rate of urinary tract infections is high in Iranian pregnant women. Pregnant women who are prone to urinary tract infections are at risk of prematurity, preterm delivery, low birth weight, high blood pressure, preeclampsia, anemia, maternal death [32]. Additionally, the presence or absence of anticoagulants may impact the connection of bacteria to

Table 2. Relationship between blood groups and bacteriuria

\begin{tabular}{|c|c|c|c|c|c|}
\hline \multirow{2}{*}{ Statistics } & \multicolumn{4}{|c|}{ No. (\%) } & \multirow{2}{*}{$\begin{array}{l}\text { Blood type } \\
\text { Bacteriuria }\end{array}$} \\
\hline & 0 & $A B$ & B & A & \\
\hline$d f=3$ & $28(48.3)$ & $2(3.4)$ & $17(29.3)$ & $11(19)$ & Yes \\
\hline \multirow{3}{*}{$P=0.001$} & $157(45.9)$ & $36(10.5)$ & $41(12)$ & $108(31.6)$ & No \\
\hline & & & & & \\
\hline & $185(46.2)$ & $38(9.5)$ & $58(14.5)$ & $119(29.8)$ & Total \\
\hline
\end{tabular}


Table 3. The relationship between bacteriuria and demographic characteristics

\begin{tabular}{|c|c|c|c|}
\hline \multicolumn{2}{|c|}{ Bacteriuria } & \multirow{2}{*}{$\begin{array}{c}\text { No. (\%) } \\
219(54.8)\end{array}$} & \multirow{2}{*}{$\begin{array}{c}\text { Statistics } \\
\text { df }=1\end{array}$} \\
\hline \multirow{3}{*}{ Educational level } & University & & \\
\hline & & & \\
\hline & Non-university & $181(45.2)$ & $P=0.944$ \\
\hline \multirow{5}{*}{ Gestational age } & First three months & $112(28)$ & \\
\hline & & & $d f=2$ \\
\hline & Second-quarter & 79(19.8) & \\
\hline & & & $P=0.016$ \\
\hline & Third-quarter & $209(52.2)$ & \\
\hline \multirow{3}{*}{ Place of residence } & City & $303(75.8)$ & $d f=1$ \\
\hline & & & \\
\hline & Village & $97(24.2)$ & $P=0.494$ \\
\hline
\end{tabular}

the epithelial cells of the urinary tract [33]. The binding of bacteria to host cells is an essential step in the development of the disease; therefore, these antigens can act as the binding site of the bacterium to the cells of the body [34].

In total, 400 pregnant women referred to Allameh Behlool Hospital in Gonabadi were studied; of them, 58(14.5\%) were bacteriologically positive. The overall prevalence of bacteriuria in pregnancy in Iran was reported as 10.4-7.2 [3]. In our study, the prevalence of bacteriuria in Gonabad was measured as $14.5 \%$ and in Ghohestani study, the prevalence of asymptomatic bacteriuria in pregnant women in Sabzevar equaled 7\% [21]. Other studies conducted in Shiraz (5.1) [35], Torbat Heydariyeh (10\%) [30] also reported this rate. Various reasons for this difference are conceivable; perhaps the main reason for the difference in the frequency of women participating in the study and the accuracy of different laboratories and socioeconomic characteristics. Besides, geographical area, province, and educational level can contribute to the lack of correlation between studies. The prevalence of bacteriuria during pregnancy is affected by several factors, such as multiple pregnancies, age, a history of urinary tract infection, diabetes, anatomical abnormalities of the urinary tract, the lack of personal hygiene, and socioeconomic status $[36,37]$.

The present study found a relationship between blood group and bacteriuria; phenotypes $\mathrm{O}$ and then $\mathrm{B}$ were the most common blood phenotypes concerning bacteriuria. This finding was consistent with those of Safarkar. They concluded that the association between bacterial urinary tract infection and blood group $\mathrm{O}$ was the most prevalent phenotype respecting urinary tract infection [38]. Benil et al.'s (2018) documented a link between lower urinary tract infection and blood type A [39]. Inconsistent with Kinane and Hooton's study that suggested no association between blood type and urinary tract infection [40, 41], and with the study of Ghasemi et al. that the relationship between blood type and the type of bacteria causing urinary tract infection was performed, there was a significant relationship between blood type and the incidence of urinary tract infections in women [42]. Perhaps one of the reasons for the difference between the results of different studies in this field can be considered in the type and the characteristics of studied patients.

This study revealed a significant relationship between gestational age and bacteriuria. It has the highest prevalence in the third trimester of pregnancy and was consistent with the present study [43]; respecting physiological and anatomical changes in pregnant women, they were also justified with increased gestational age and elevated risk of urinary tract infections.

Moreover, there was no significant relationship between educational level and bacteriuria; although in some studies, this finding did not correspond to the results, as there was a relationship between educational level and bacteriuria $[44,45]$.

\section{Conclusion}

According to the present study results, bacteriuria in pregnant women in Gonabad City, Iran, is reported to be $14.5 \%$; thus, it recommends education about the signs and symptoms related to bacteriuria and the timely referral of pregnant women to community health centers to prevent maternal and embryo complications. Bacteriuria is also more common in pregnant women with the blood group $\mathrm{O}$, followed by $\mathrm{B}$, indicating the greater importance of these groups for urinary screening. Women and mothers are the foundation of the family and public health; therefore, it is recommended that the right decision be made to prevent, screen, and treat this 
problem. A limitation of this study was its restricted implementation to the population of pregnant women. This study was performed only in pregnant women; thus, conducting similar studies with the target population of men and women may present different results.

\section{Ethical Considerations}

\section{Compliance with ethical guidelines}

This study was approved by the ethics committee of the Gonabad University of Medical Sciences (Ethics Code: IR.GMU.REC.1397.069).

Funding

This study was conducted at the Gonabad University of Medical Sciences.

\section{Authors' contributions}

Writing - original draft: All authors; Conceptualization: Azam Sadat Mahmoudian and Amir Jarhi; Final approval: Mitra Jaras and Abdul Javad Khajavi; Data analysis: Seyed Farzin Mircheraghi and Azam Sadat Mahmoudian; Methodology and data collection: Amir Jarhi and Mitra Jaras.

\section{Conflicts of interest}

The authors declared no conflicts of interest.

\section{Acknowledgements}

The authors express their gratitude to the Vice-Chancellor for Research and Technology of Gonabad University of Medical Sciences and also to the Medical School of Gonabad University of Medical Sciences. 
This Page Intentionally Left Blank 


\section{شيوع باكثريورى و ارثباط بين تروه خونى ABO و باكتريورى در زنان باردار مراجعه كثنده به

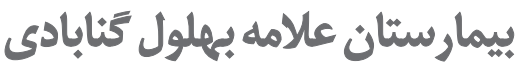

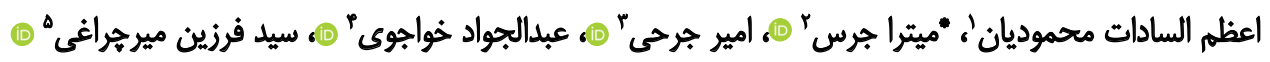

1. كروه بيمارى هاى زنان و زايمان، دانشكده هزشكى، دانشعاه علوم يزشكى كناباد، كثناباد، ايران.

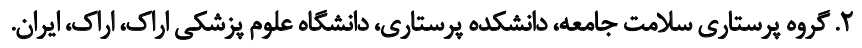

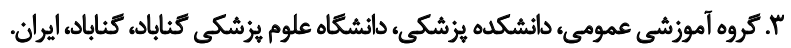

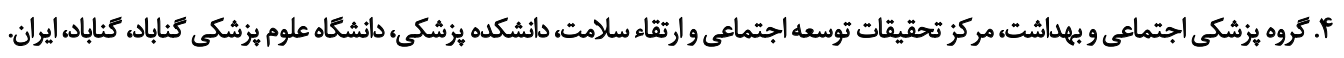

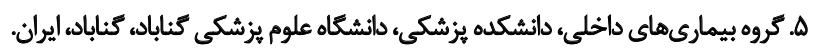

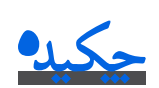

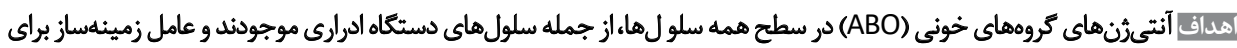

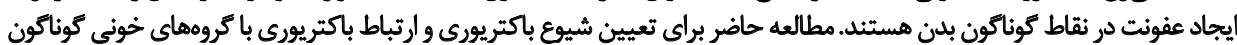

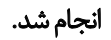

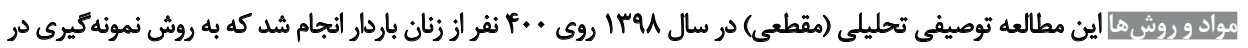

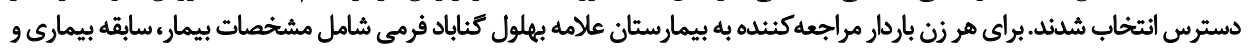

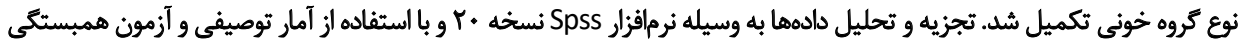

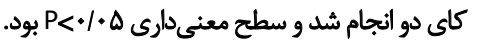

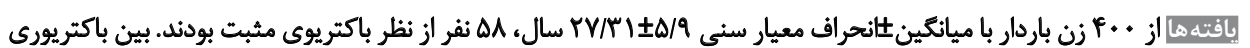

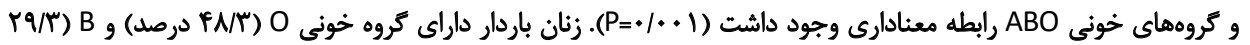

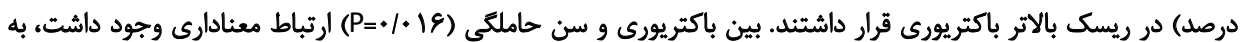

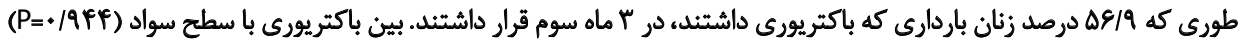

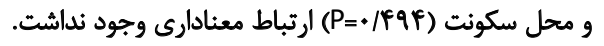

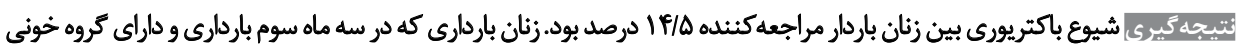

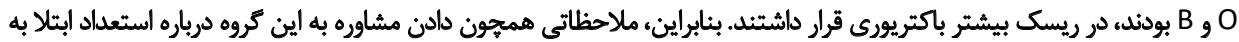

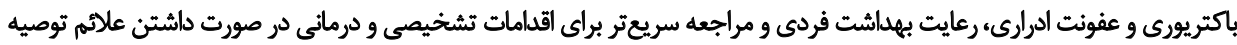

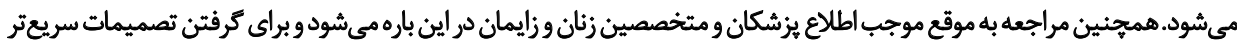
كمككنيده خواهد بودي.

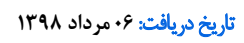

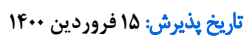

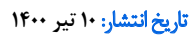

دستكاه ادرارى تحتانى را دركير كند (سيستيت و اورتريت).

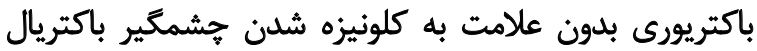

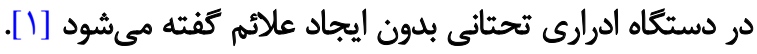

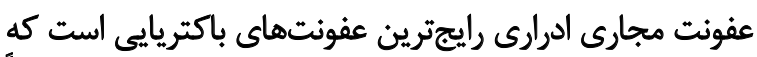

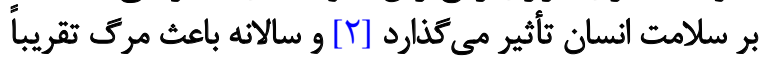

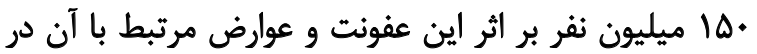

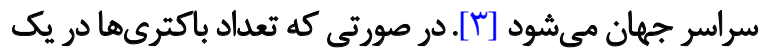

باكتريورى به هرگونه كلونيزه شدن باكترىها در دستكاه

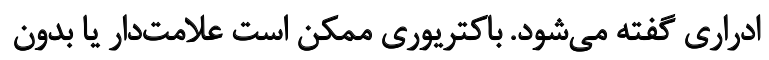

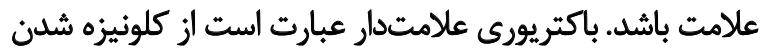

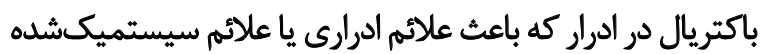

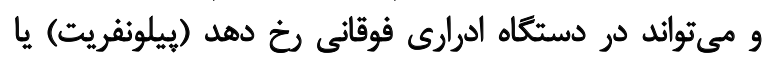


از عفونتها، ايديوياتيك بوده و درك عوامل خطر احتمالى مؤثر

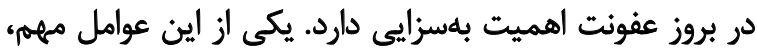

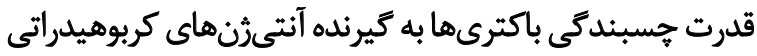
سطح سلولهاى دستكاه ادرارى ميزبان است. كَليكويروتئينين

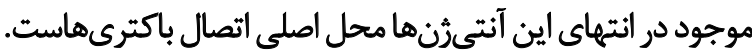

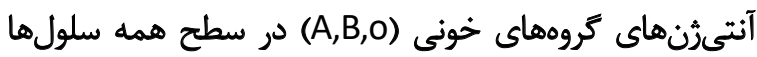

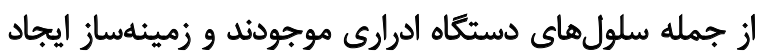

عفونت در نقاط كوناكون بدن هستند [19].

كروههاى خونى، سيستمى از آنتى رُنهائ اريتروسيتى هستند

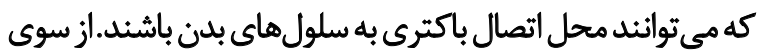

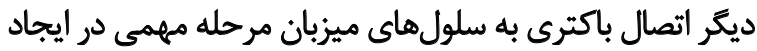

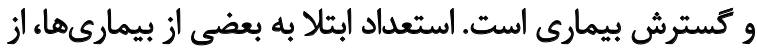

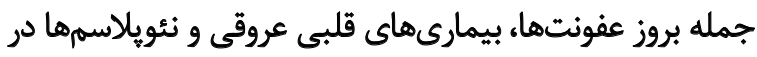

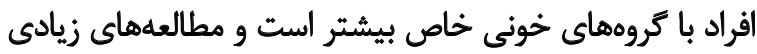

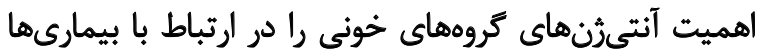

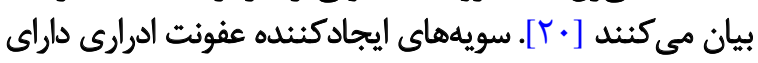

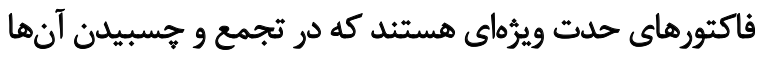

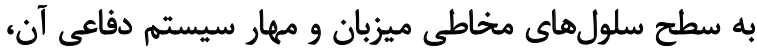

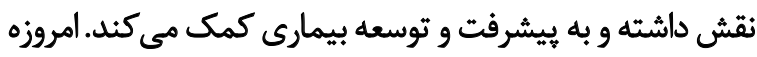

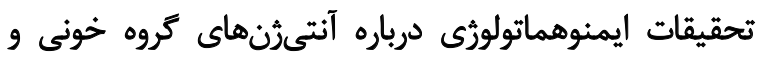

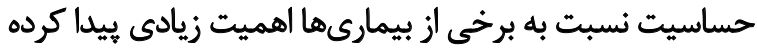

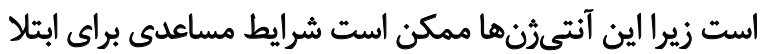

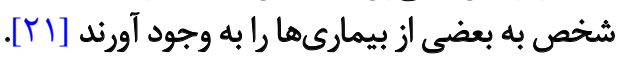

استعداد ابتلا به بعضى بيمارى ها از جمله بروز عفونتهادي ادر افراد

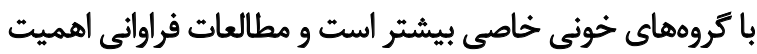

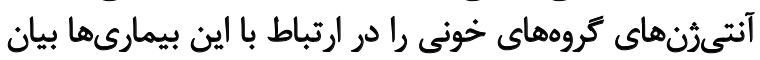

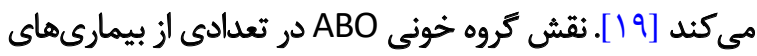

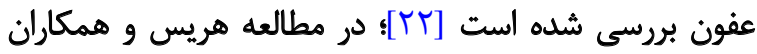

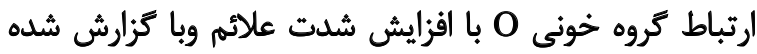

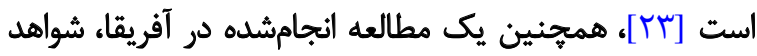

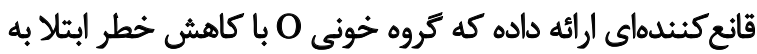

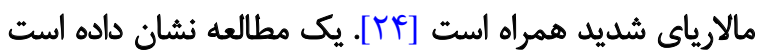

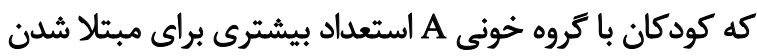

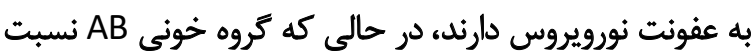

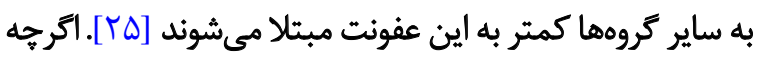

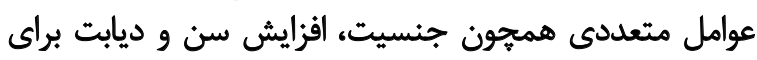

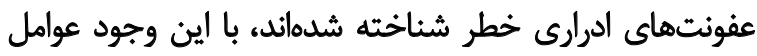

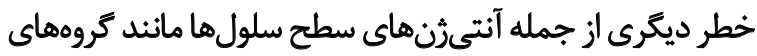

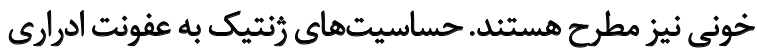

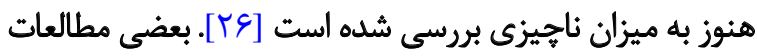

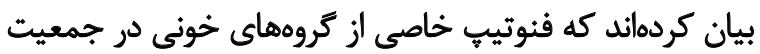

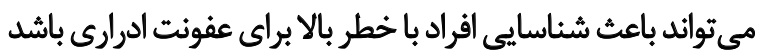

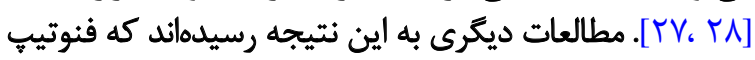

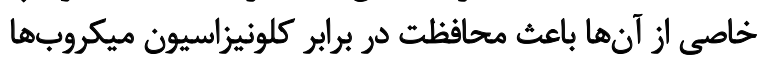

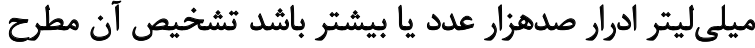

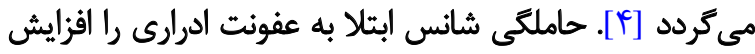

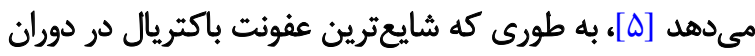

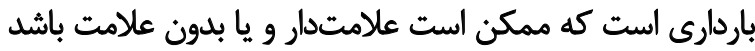

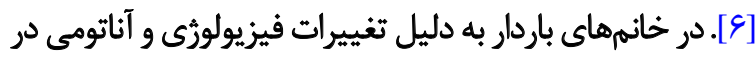

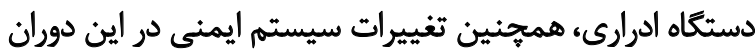

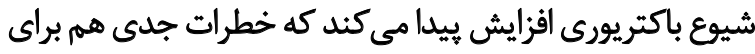

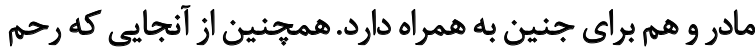

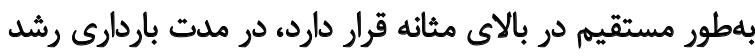

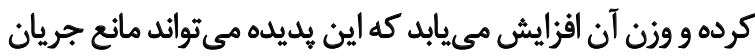

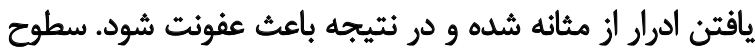

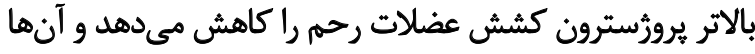

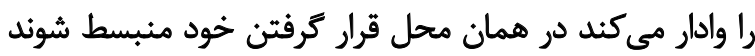

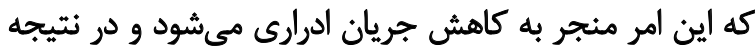

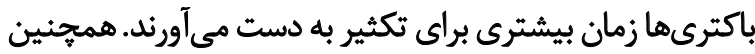

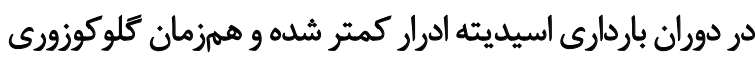

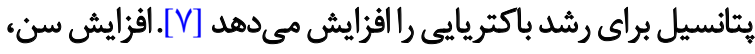

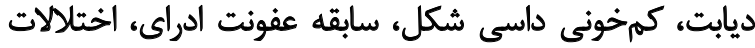

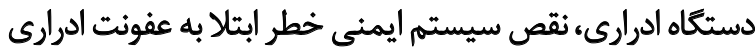

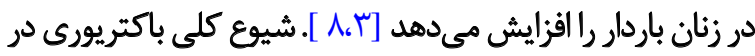

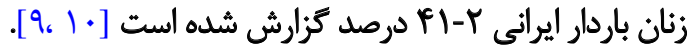
ميزان عفونت ادرارى در كشورهاى در حال توسعه حداقل

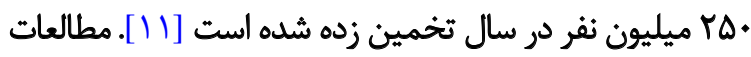

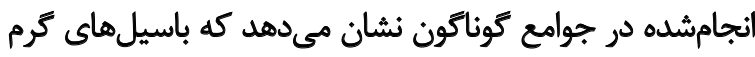

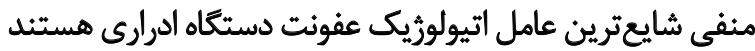

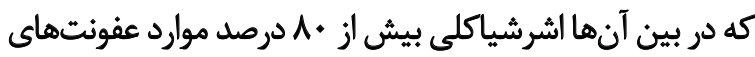

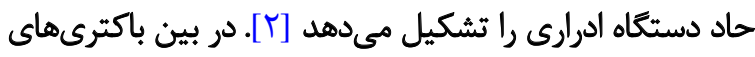

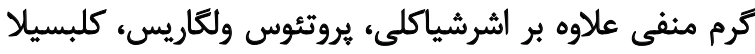

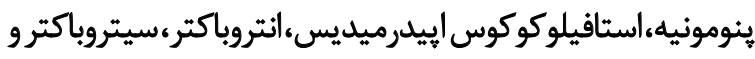

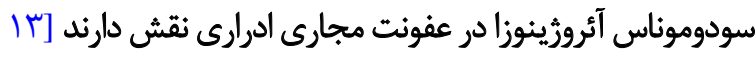

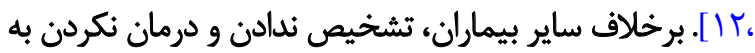

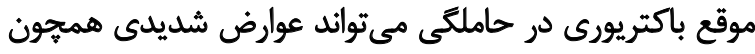

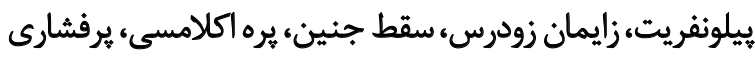

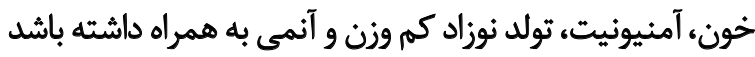

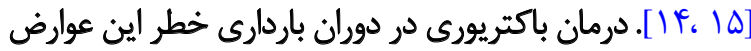

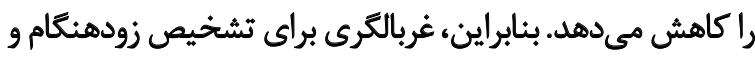

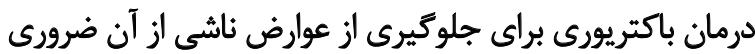

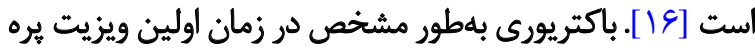

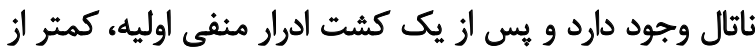

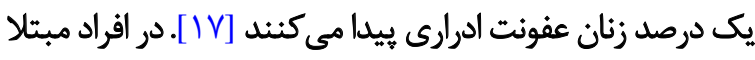

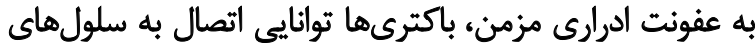

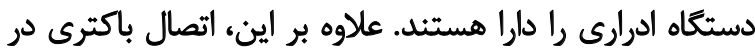

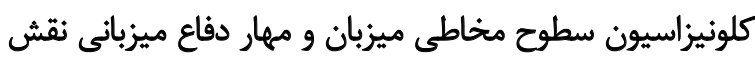

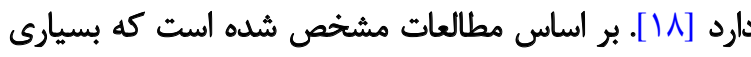


تعيين كروه خونى به هر دو روش سل تايب' يا فوروارد تايڤّ

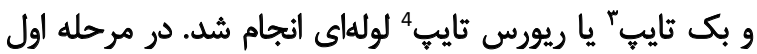

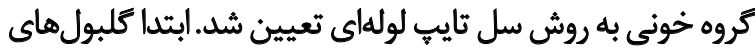

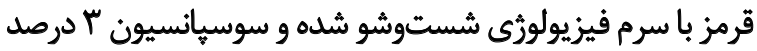

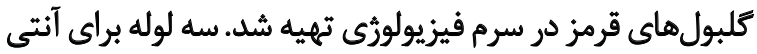

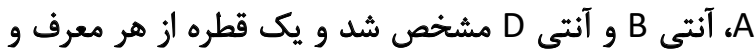

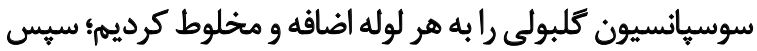

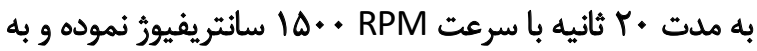

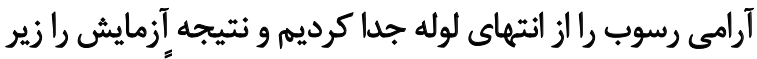

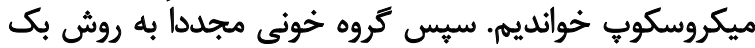

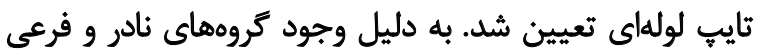

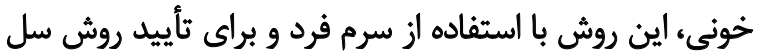

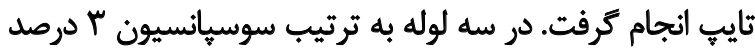

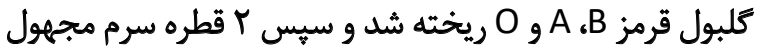

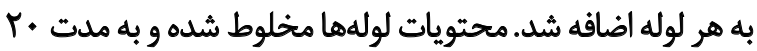

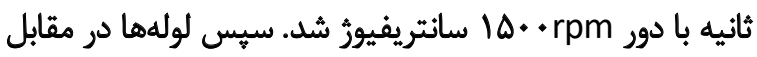

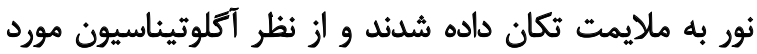

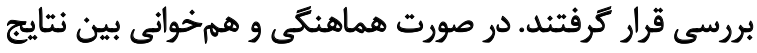

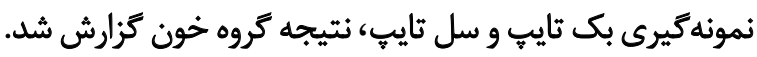

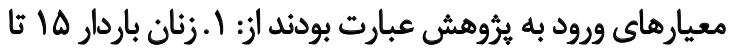

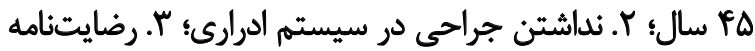

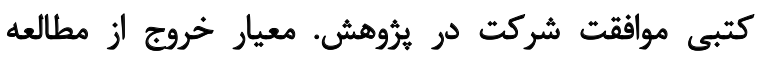

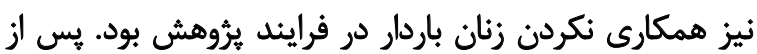

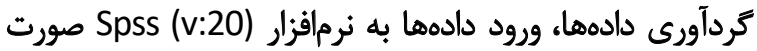

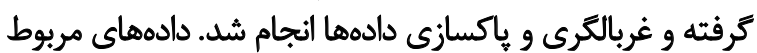

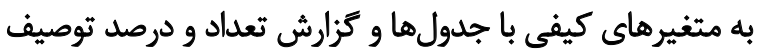

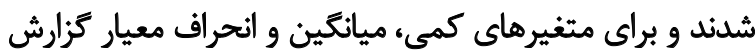

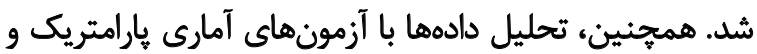

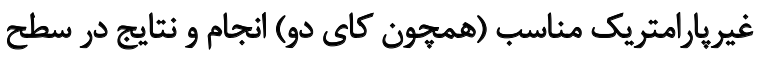

$$
\text { معنى دارى ه • •• تفسير شد. }
$$

يافتهها

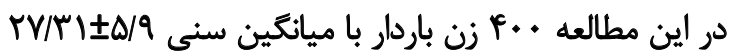

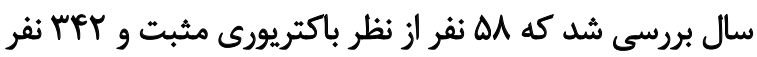

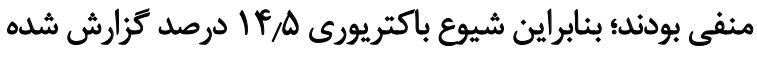

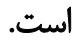

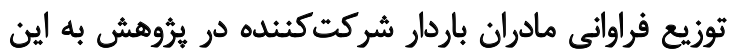

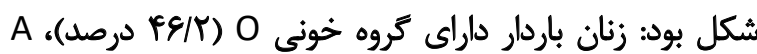

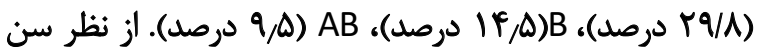

1. Typing Cell

2. Typing Forward

3. Typing Back

4. Typing Reverse

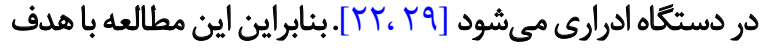

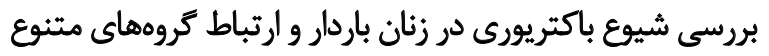

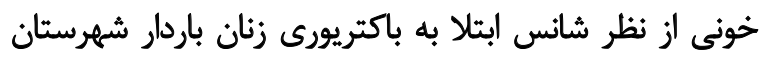

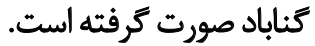

\section{مواد و روشها}

آين مطالعه مقطعى با هدف بررسى شيوع باكتريورى و ارتباط

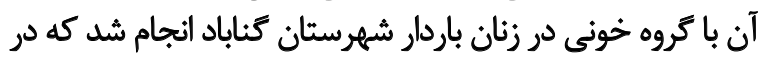

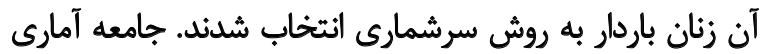

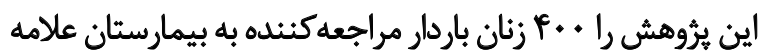

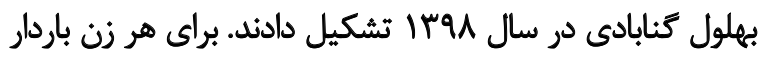

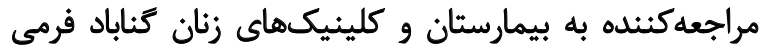

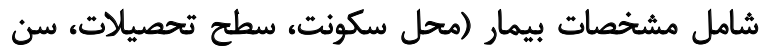

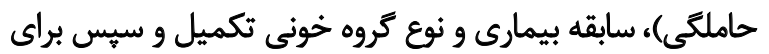

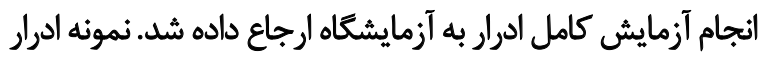

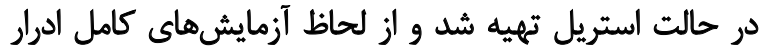

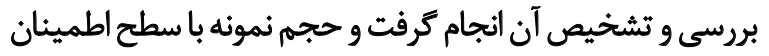

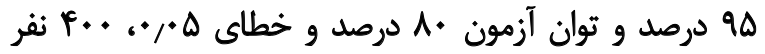

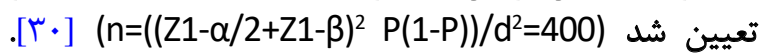

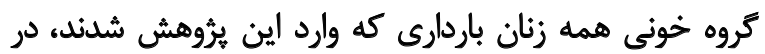

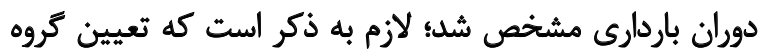

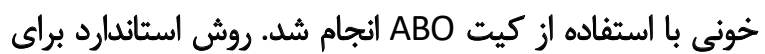

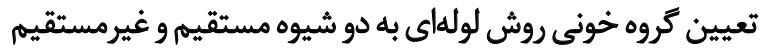

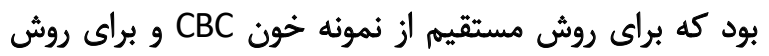

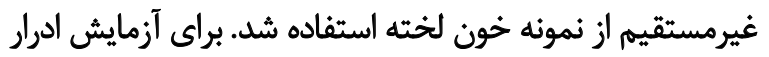
نيز از تست U/A استفاده شد.

\section{أزوهايش ادوار}

در اين بررسى نمونههاى ادرارى زنان باردار مراجعهكنينده

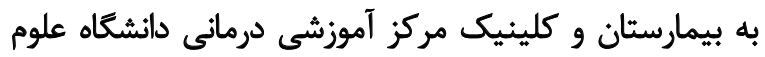

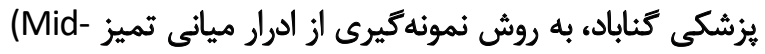
stream clean catc)

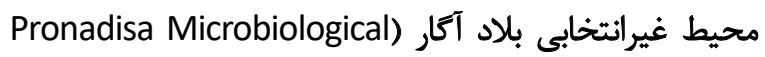
(Culture Media and Diagnotic Reagent, spain

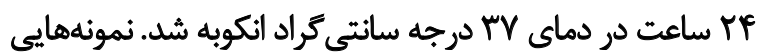

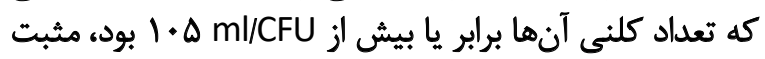

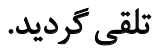

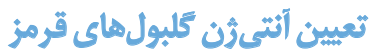

تعيين كروههاي خونى Rh و ABO با استفاده از كيت The UK Lorne Blood Grouping Reagents 
جدول ا. توزيع فراوانى باكتريورى

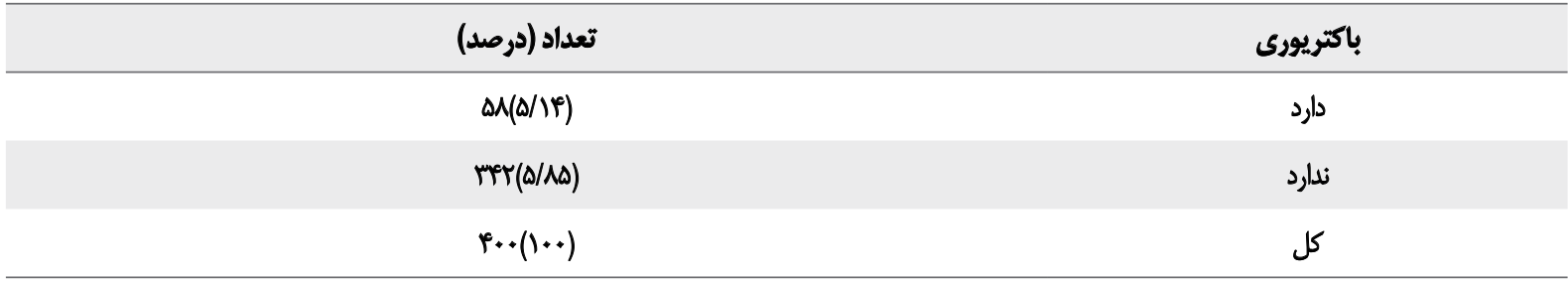

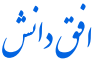

استفاده شد كه رابطه معنى دارى بين باكتريورى و كروه خونى (بري

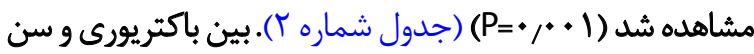
حاملكى (19)

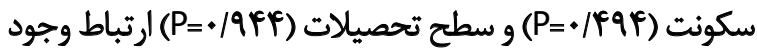

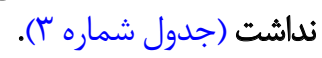

بحث

هدف از اين مطالعه بررسى شيوع باكتريورى و ارتباط بين كروه

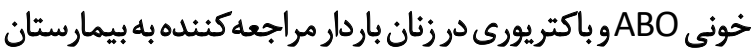

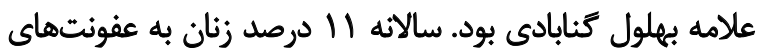

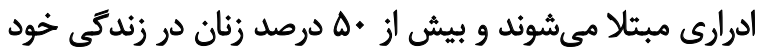

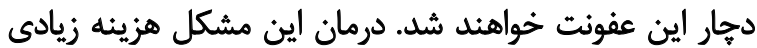

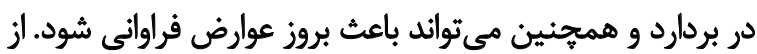

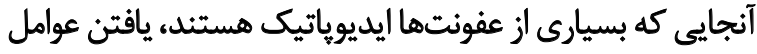

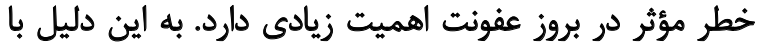

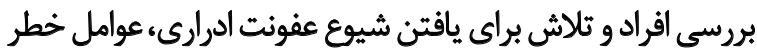

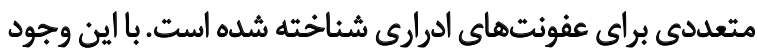
عوامل خطر جديدى از جمله آنتىثنهاى سطح سلى سلولهانها مانند

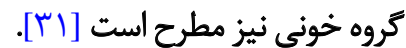

ميزان عفونت ادرارى در زنان باردار ايرانى بالاست. زنان باردار

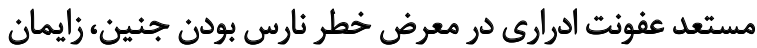

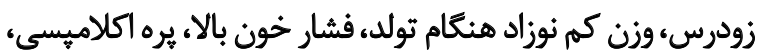

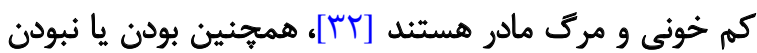

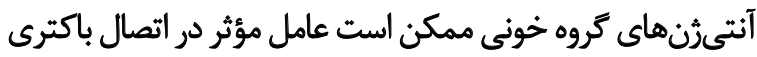

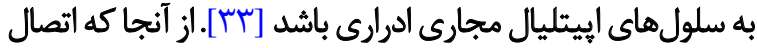

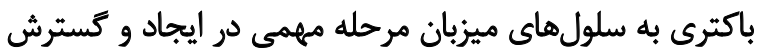

بارداري، Y د درصد در سه ماهه اول، 19/1 درصد در سه ماهيه

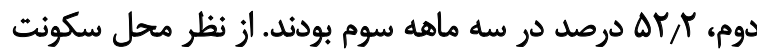

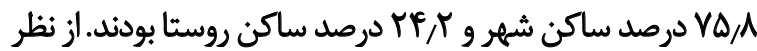
تحصيلات بودند.

توزيع فروانى در خانمهاى باردارى كه مبتلا به باكتريورى دوري

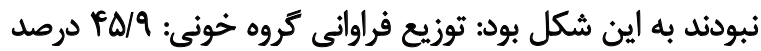

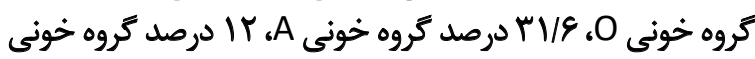

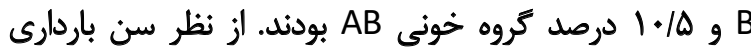

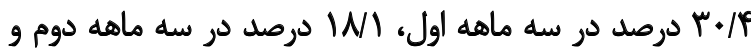

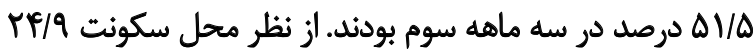

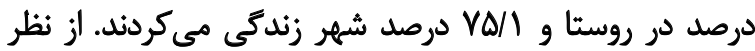

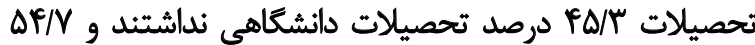

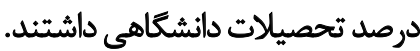

توزيع فروانى در خانمهاى باردارى كه مبتلا به باكتريورى بودند

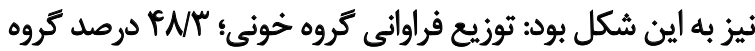

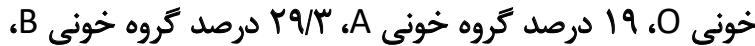

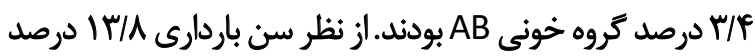

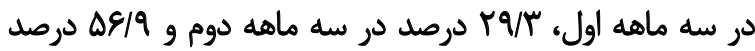

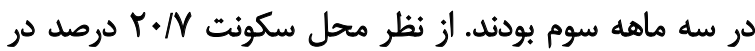

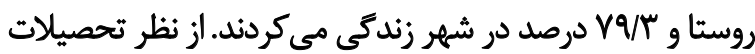

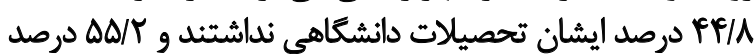
تحصيلات دانشكاهي داشتند. اين مطالعه باكتريورى دارئد (جدول شماره () ). براى مقايسه باكتريورى و گروههاى خونى،از آزمون كاى اسكور

جدول ؟. رابطه كروهماى خونى با باكتريورى

\begin{tabular}{|c|c|c|c|c|c|}
\hline \multirow{2}{*}{ أهاروهاي أزمون } & \multicolumn{4}{|c|}{ تعداد (درصد) } & \\
\hline & 0 & AB & B & A & (1) \\
\hline$f d=r$ & $r A(F N M)$ & $r(r / p)$ & $I Y(T q / r)$ & $11(19)$ & دارد \\
\hline \multirow{2}{*}{$\mathrm{P}=. \mid . .1$} & $\left.1 \Delta Y()^{F} \Delta / q\right)$ & $r g(1 . / 0)$ & PI(IT) & I.APYV/P) & ن تلمارد \\
\hline & $M \Delta(F \& / T)$ & rN(Q/D) & $\Delta N(\mid f / \Delta)$ & $119($ (ร/1) & كل \\
\hline
\end{tabular}

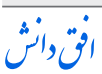


جدول "ا. رابطه باكتريورى و مشخصات جمعيتشناسى

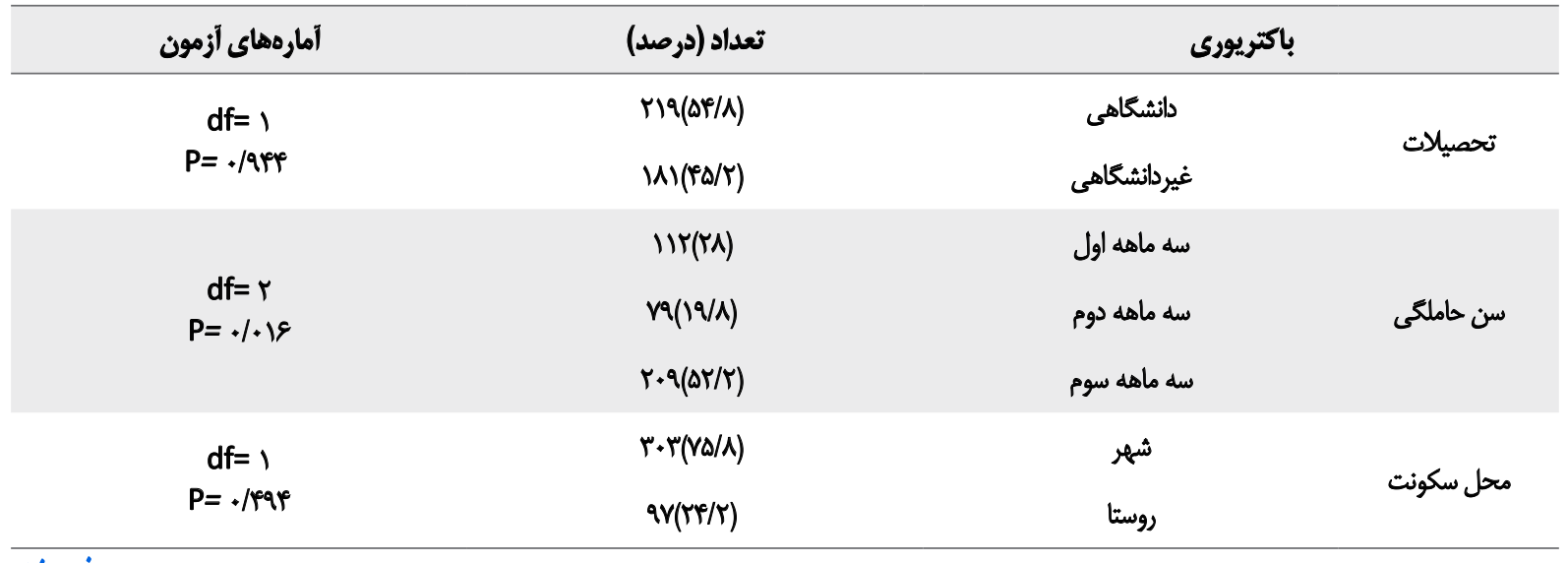

إن"ان

زنان رابطه معنى دارى يافتند [T [T] همسو بود. شايد يكى از دلايل

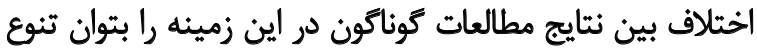

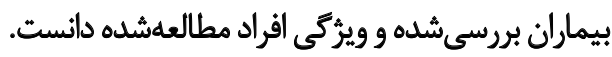
در اين مطالعه رابطه معنى دارى بين سن حاملكى و باكتريورى

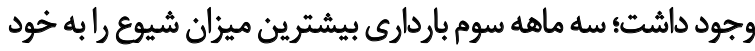

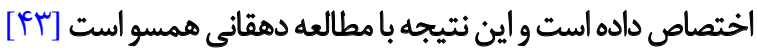

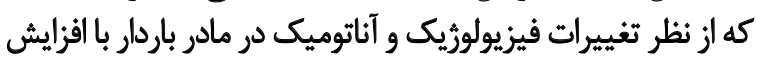

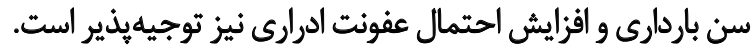
همجنين در اين مطالعه بين سطح تحصيلات و باكتريورى ارتباط

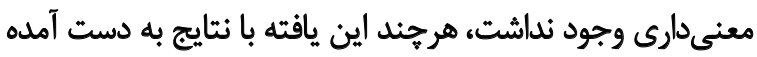

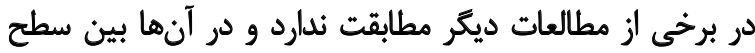

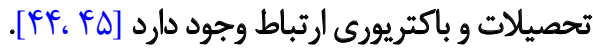
تئيجاكيرى

با توجه به نتايج مطالعه حاضر، باكتريورى در زنان باردار شهرستان

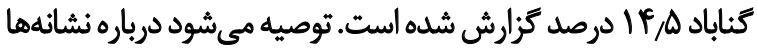

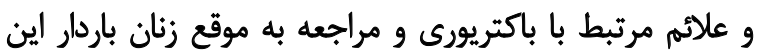

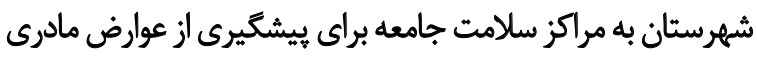

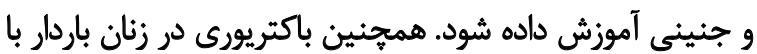

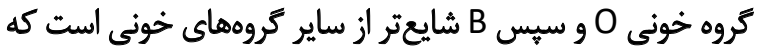

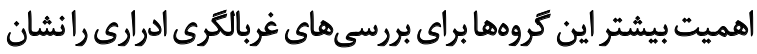

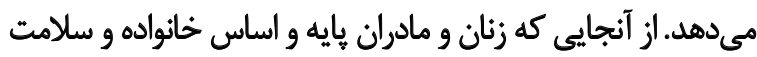

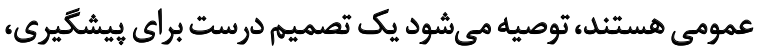

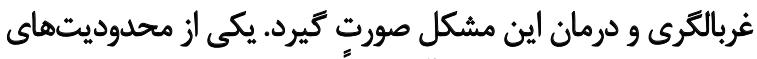

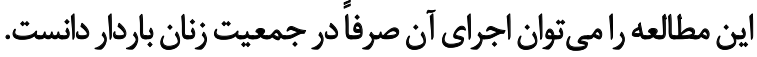

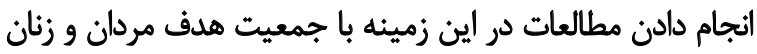
ممكن است نتايج متفاوتى داشته باشد.
بيمارى است، اين آنتىثنها مى توانند محل اتصال باكترى به

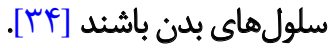

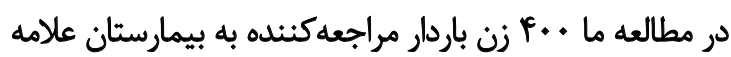

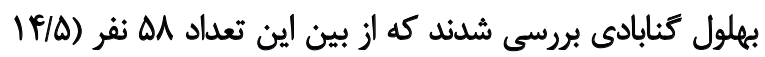

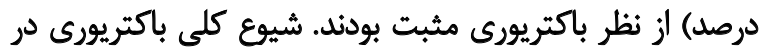

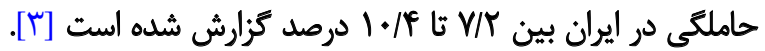

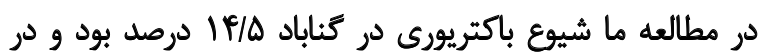

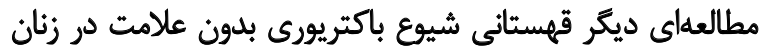

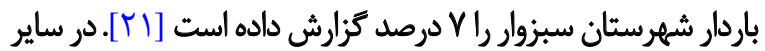

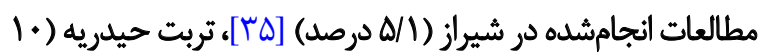

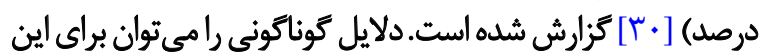

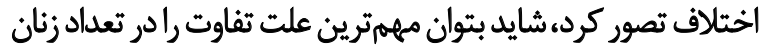

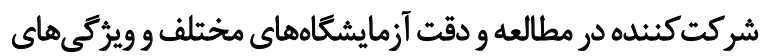

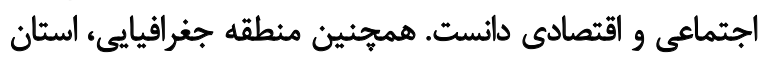

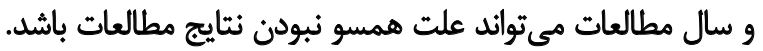

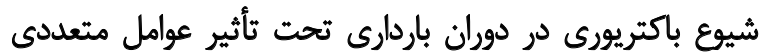

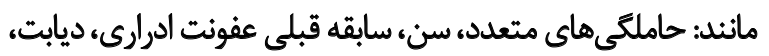

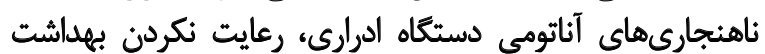

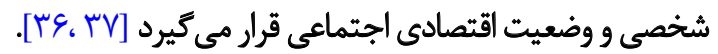
در مطالعه حاضر مشخص شد كه بين كروه خونى و باكتريورى

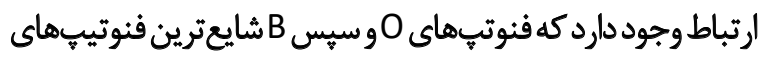

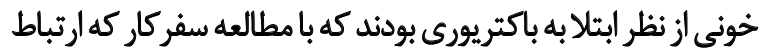

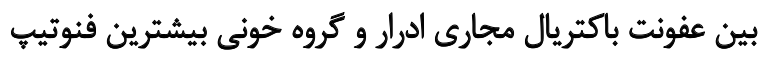

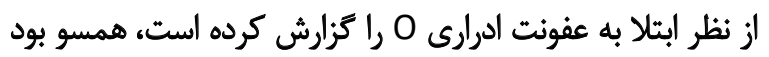

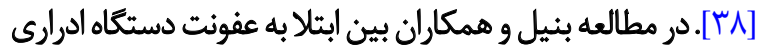

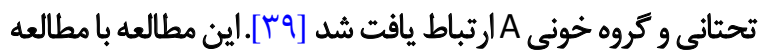

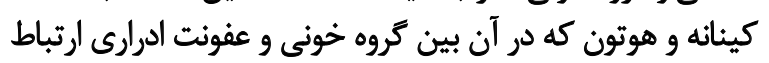

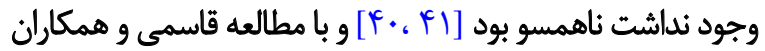

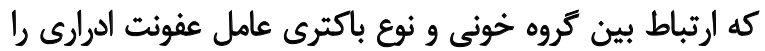

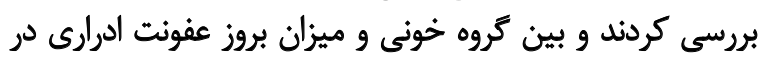




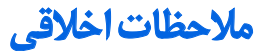

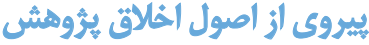

يرؤششكران همه كدهاى اخلاقى مربوط به تحقيقات روى

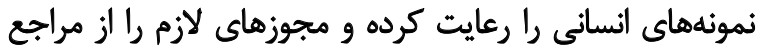

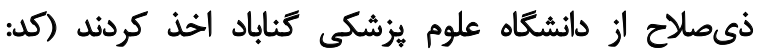

.). IR.GMU.REC.1397.069

$$
\text { مامب مالب }
$$

اين تحقيق هيج كونه كمك مالى از سازمان هاي تأمين مالى در

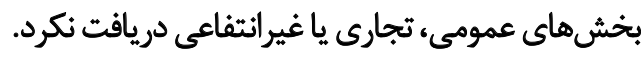

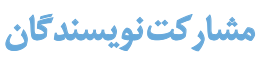

نوشتن نسخه اوليه: همه نويسندكان؛ ايده اصلى: اعظمالسادات

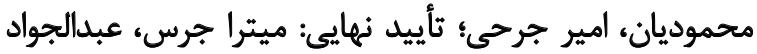

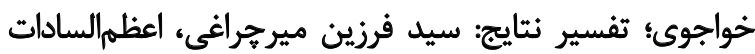
محموديان؛ طراحى مطالعه و گردآورى دادهها: امير جرحى، مئ، ميترا جرس.

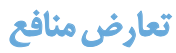

نويسندكان اين مقاله اعلام كردند كه هيج كونه تعارض منافعى

$$
\text { در اين نوشتار وجود ندارد. }
$$

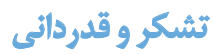

نويسندكان بر خود لازم مى دانيد مراتب تشكر خود رالز ماز معاونت

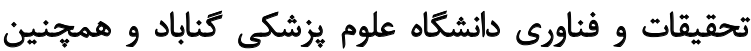
دانشكده يزشكى دانشعاه علوم يزشكى كناباد اعلاد اعلام كنند. 


\section{References}

[1] Shodjai H. [Microbiologic evaluation of bacteruria in prehnant women in Shahrekord in 1999 (Persian)]. Researcher Bulletin of Medical Sciences (Pejouhandeh). 2000; 5(3):337-42. https://www.sid.ir/fa/journal/ ViewPaper.aspx?ID=13746

[2] Foxman B, Barlow R, D’Arcy H, Gillespie B, Sobel JD. Urinary tract infection: Self-reported incidence and associated costs. Annals of Epidemiology. 2000; 10(8):509-15. [DOI:10.1016/S1047-2797(00)00072-7]

[3] Azami M, Jaafari Z, Masoumi M, Shohani M, Badfar G, Mahmudi L, et al. The etiology and prevalence of urinary tract infection and asymptomatic bacteriuria in pregnant women in Iran: A systematic review and Metaanalysis. BMC Urology. 2019; 19:43. [DOI:10.1186/s12894-019-0454-8] [PMID]

[4] MacLean AB. Urinary tract infection in pregnancy. International Journal of Antimicrobial Agents. 2001; 17(4):273-6. [DOI:10.1016/S09248579(00)00354-X] [PMID]

[5] Zeki Abbasi M, Bahtooei M, Vahdat K, Tavakolli M, Dalaki F. [Antibiotic susceptibility of microorganisms of urinary tract infection in adult outpatients in Bushehr port (Persian)]. Iranian South Medical Journal. 2008; 10(2):153-8. http://ismj.bpums.ac.ir/article-1-20-en.html

[6] Labi AK, Yawson AE, Ganyaglo GY, Newman MJ. Prevalence and associated risk factors of asymptomatic bacteriuria in ante-natal clients in a large teaching hospital in Ghana. Ghana Medical Journal. 2015; 49(3):154-8. [DOI:10.4314/gmj.v49i3.5] [PMID]

[7] El-Kashif MML. Urinary tract infection among pregnant women and its associated risk factors: A cross-sectional study. Biomedical and Pharmacology Journal. 2019; 12(4):2003-10. [DOI:10.13005/bpj/1832]

[8] Raza S, Pandey S, Bhatt CP. Microbiological analysis of isolates in Kathmandu Medical College Teaching Hospital, Kathmandu, Nepal. Kathmandu University Medical Journal. 2011; 9(36):295-7. [PMID]

[9] Smaill FM, Vazquez JC. Antibiotics for asymptomatic bacteriuria in pregnancy. The Cochrane Database of Systematic Reviews. 2007; (2):CD000490. [DOI:10.1002/14651858.CD000490.pub2] [PMID]

[10] Azhari S, Mousavi Yazd M, Sojudi Moghaddam MH, Ebrahim Zadeh $\mathrm{S}$. [Accuracy of urine dipslide to detect asymptomatic bacteriuria in pregnancy (Persian)]. The Iranian Journal of Obstetrics, Gynecology and Infertility. 2012; 15(3):8-14. [DOI:10.1002/14651858.CD000490.pub4]

[11] Kothari A, Sagar V. Antibiotic resistance in pathogens causing community-acquired urinary tract infections in India: A multicenter study. The Journal of Infection in Developing Countries. 2008; 2(05):354-8. [DOI:10.3855/jidc.196]

[12] Flores-Mireles AL, Walker JN, Caparon M, Hultgren SJ. Urinary tract infections: Epidemiology, mechanisms of infection and treatment options. Nature Reviews. Microbiology. 2015; 13(5):269-84. [DOI:10.1038/ nrmicro3432] [PMID]

[13] Martins A, Hunyadi A, Amaral L. Mechanisms of resistance in bacteria: An evolutionary approach. The Open Microbiology Journal. 2013; 7(Suppl 1):53-8. [DOI:10.2174/1874285801307010053] [PMID]

[14] Glaser AP, Schaeffer AJ. Urinary tract infection and bacteriuria in pregnancy. The Urologic clinics of North America. 2015; 42(4):547-60. [DOI:10.1016/j.ucl.2015.05.004] [PMID]

[15] Izadi B, Rostami-Far Z, Jalilian N, Khazaei S, Amiri A, Madani S, et al. Urinary Tract Infection (UTI) as a risk factor of severe preeclampsia. Global Journal of Health Science. 2016; 8(9):77-82. [DOl:10.5539/gihs. v8n11p77]
[16] Smaill FM, Vazquez JC. Antibiotics for asymptomatic bacteriuria in pregnancy. Cochrane Database of Systematic Reviews. 2015 (8):CD000490. [DOI:10.1002/14651858.CD000490.pub3]

[17] Whalley PJ, Cunningham FG. Short-term versus continuous antimicrobial therapy for asymptomatic bacteriuria in pregnancy. Obstetrics and Gynecology. 1977; 49(3):262-5. [PMID]

[18] Svanborg-Edén C, Jodal U. Attachment of Escherichia coli to urinary sediment epithelial cells from urinary tract infection-prone and healthy children. Infection and Immunity. 1979; 26(3):837-40. [DOI:10.1128/ iai.26.3.837-840.1979] [PMID]

[19] Tanagho EA. Smith's general urology. $17^{\text {th }}$ ed. New York: McGraw-Hill; 2007. pp. 193-234.

[20] Weiss FU, Schurmann C, Teumer A, Mayerle J, Simon P, Völzke H, et al. ABO blood type $B$ and fucosyltransferase 2 non-secretor status as genetic risk factors for chronic pancreatitis. Gut. 2016; 65(2):353-4 [DOI:10.1136/gutjnl-2015-309682] [PMID]

[21] Adamian RT. [Blood-type and rhesus distribution in Armenian women with endometrial carcinoma (Russian)]. Voprosy Onkologii. 2005 51(5):575-6. [PMID]

[22] Cooling L. Blood groups in infection and host susceptibility. Clinical Microbiology Reviews. 2015; 28(3):801-70. [DOI:10.1128/CMR.00109-14] [PMID]

[23] Harris JB, LaRocque RC. Cholera and ABO blood group: Understanding an ancient association. The American Journal of Tropical Medicine and Hygiene. 2016; 95(2):263-4. [DOI:10.4269/ajtmh.16-0440] [PMID]

[24] Degarege A, Gebrezgi MT, Ibanez G, Wahlgren M, Madhivanan P. Effect of the $A B O$ blood group on susceptibility to severe malaria: $A$ systematic review and meta-analysis. Blood Reviews. 2019; 33:53-62. [DOI:10.1016/j.blre.2018.07.002] [PMID]

[25] Nasir W, Frank M, Kunze A, Bally M, Parra F, Nyholm PG, et al. Histoblood group antigen presentation is critical for binding of norovirus VLP to glycosphingolipids in model membranes. ACS Chemical Biology. 2017 12(5):1288-96. [DOI:10.1021/acschembio.7b00152] [PMID]

[26] Sobel J, Brown P. Urinary tract infections. In: Bennett JE, Dolin R, Blaser MJ. Mandell, Douglas, and Bennett's Principles and Practice of Infectious Diseases. Amsterdam: Elsevier Health Sciences; 2019. https:// www.google.com/books/edition/Mandell_Douglas_and_Bennett_s_ Principles/8pKqDwAAQBAJ?hl=en

[27] Sheinfeld J, Schaeffer AJ, Cordon-Cardo C, Rogatko A, Fair WR. Association of the Lewis blood-group phenotype with recurrent urinary tract infections in women. New England Journal of Medicine. 1989; 320(12):773-7. [DOI:10.1056/NEJM198903233201205] [PMID]

[28] Ziegler T, Jacobsohn N, Fünfstück R. Correlation between blood group phenotype and virulence properties of Escherichia coli in patients with chronic urinary tract infection. International Journal of Antimicrobial Agents. 2004; 24(Suppl 1):70-5. [DOI:10.1016/j.jjantimicag.2004.03.002] [PMID]

[29] Franchini M, Bonfanti C. Evolutionary aspects of $A B O$ blood group in humans. Clinica Chimica Acta. 2015; 444:66-71. [DOI:10.1016/j. cca.2015.02.016

[30] Kameli M, Badiee M, Rafiee M. [Prevalence of asymptomatic bacteriuria and its treatment in pregnant women referred to health centers of Torbat Haydarieh in 2013 (Persian)]. Journal of Torbat Heydariyeh University of Medical Sciences. 2013; 1(3):58-65. http://jms.thums.ac.ir/ article-1-48-en.html 
[31] Shoaf-Sweeney KD, Hutkins RW. Adherence, anti-adherence, and oligosaccharides preventing pathogens from sticking to the host. Advances in Food and Nutrition Research. 2009; 55:101-61. [DOI:10.1016/ S1043-4526(08)00402-6] [PMID]

[32] Tadesse S, Kahsay T, Adhanom G, Kahsu G, Legese H, G/Wahid A, et al. Prevalence, antimicrobial susceptibility profile and predictors of asymptomatic bacteriuria among pregnant women in Adigrat General Hospital, Northern Ethiopia. BMC Research Notes. 2018; 11:740. [DOI:10.1186/s13104-018-3844-1] [PMID]

[33] Emody L, Kerenyi M, Nagy G. Virulence factors of uropathogenic Escherichia coli. International Journal of Antimicrobial Agents. 2003; 22(Suppl 2):29-33. [DOI:10.1016/S0924-8579(03)00236-X] [PMID]

[34] Shahi H, Moghni M, Bahreini R, Reiisi S, Sadeghiani M, Rahimi M, et al. Association between $\mathrm{H}$. pylori babA virulence factor with clinical outcome and $A B O$ blood groups. Journal of Pure and Applied Microbiology. 2015; 9:285-90. http://eprints.skums.ac.ir/id/eprint/1883

[35] Kasraeian M, Asadi N, Ghaffarpasand F. Prevalence of asymptomatic bacteriuria among pregnant women in Shiraz, Iran. Saudi Medical Journal. 2009; 30(7):917-20. [PMID]

[36] Al-Haddad AM. Urinary tract infection among pregnant women in AlMukalla district, Yemen. Eastern Mediterranean Health Journal. 2005; 11(3):505-10. [PMID]

[37] Bandyopadhyay S, Thakur JS, Ray P, Kumar R. High prevalence of bacteriuria in pregnancy and its screening methods in north India. Journal of the Indian Medical Association. 2005; 103(5):259-62, 266. [PMID]

[38] Safarkar R, Bonabi R, Massiha AR, Dejagah S, Khani S, Abafat N, et al. [Relationship between urinary tract bacterial infections and blood groups in patients referring to Alavi Hospital in Ardabil, Iran in 1395 (Persian)]. Scientific Journal of Nursing, Midwifery and Paramedical Faculty. 2018; 4(1):41-51. http://sjnmp.muk.ac.ir/article-1-148-en.html

[39] Benli E, Çırakoğlu A, Öğreden E, Kaya Y, Ayyıldız A, Yüce A. Do ABO blood groups affect lower urinary tract symptoms? Turkish Journal of Urology. 2019; 45(Suppl 1):S84-91. [DOI:10.5152/tud.2018.25295] [PMID]

[40] Kinane DF, Blackwell CC, Brettle RP, Weir DM, Winstanley FP, Elton RA. $A B O$ blood group, secretor state, and susceptibility to recurrent urinary tract infection in women. British Medical Journal. 1982; 285(6334):7-9. [DOI:10.1136/bmj.285.6334.7] [PMID]

[41] Hooton TM, Scholes D, Hughes JP, Winter C, Roberts PL, Stapleton AE, et al. A prospective study of risk factors for symptomatic urinary tract infection in young women. The New England Journal of Medicine. 1996; 335(7):468-74. [DOI:10.1056/NEJM199608153350703] [PMID]

[42] Ghasemi N, Ayatollahi J, Mosadegh A, Mahdavi SM. [Relationship between $\mathrm{ABO}$ blood group antigens and the type of pathogen in urinary tract infection in patiens referredto university laoratorie in Yazd (Persian)]. The Scientific Journal of Iranian Blood Transfusion Organization. 2009; 5(4):267-73. http://bloodjournal.ir/article-1-275-fa.html

[43] Dehghani A, Zahedi M, Moezzi M, Dafei M, Falahzadeh H. [Survey of risk factors urinary tract infection (Persian)]. Tolooebehdasht. 2016; 15(3):92-102. http://tbj.ssu.ac.ir/article-1-2274-fa.html

[44] Patterson TF, Andriole VT. Detection, significance, and therapy of bacteriuria in pregnancy: Update in the managed health care era. Infectious Disease Clinics of North America. 1997; 11(3):593-608. [DOI:10.1016/ S0891-5520(05)70375-5] [PMID]

[45] Golan A, Wexler S, Amit A, Gordon D, David MP. Asymptomatic bacteriuria in normal and high-risk pregnancy. European Journal of Obstetrics \& Gynecology and Reproductive Biology. 1989; 33(2):101-8. [DOI:10.1016/0028-2243(89)90202-5] 
This Page Intentionally Left Blank 